\title{
Maling til besvær
}

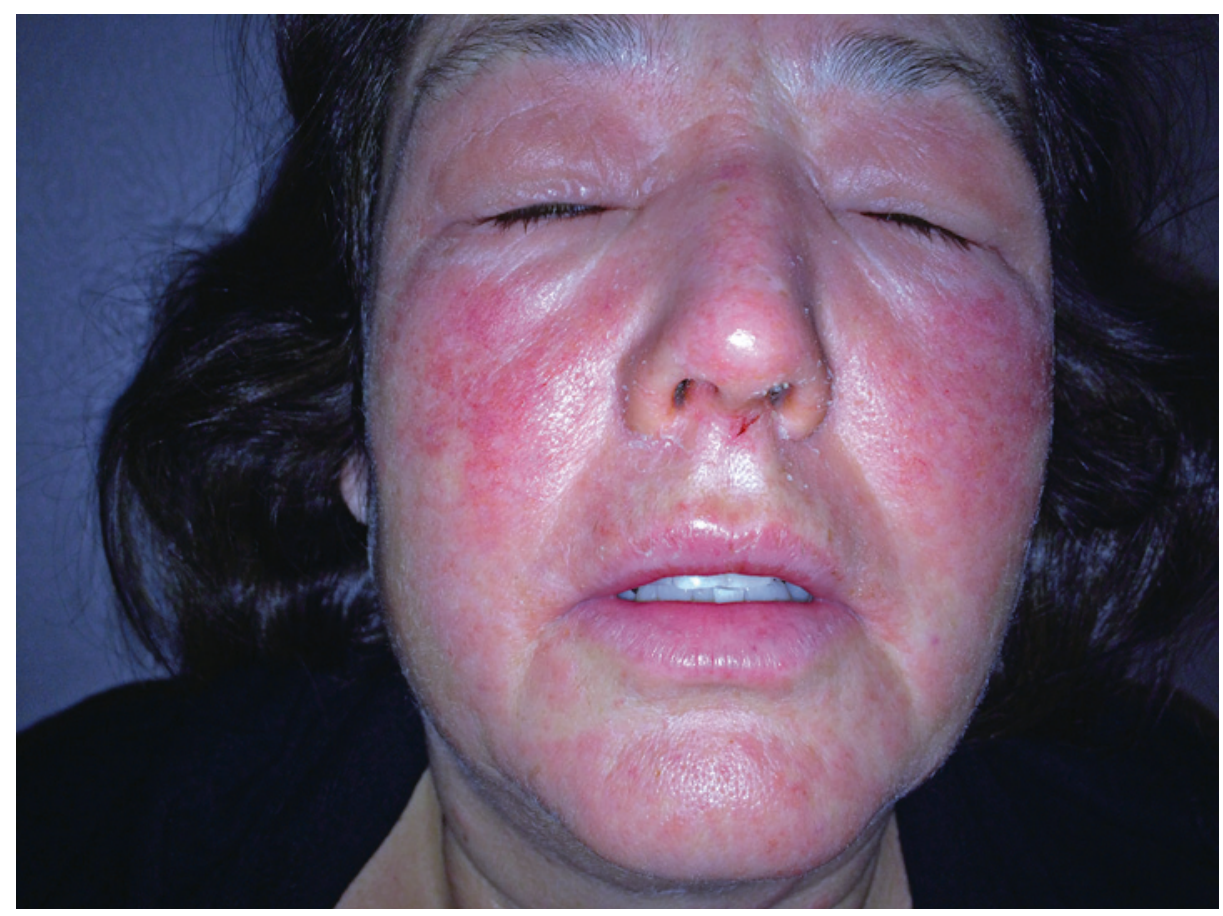

En kvinne i 40-årene fikk et økende utslett i ansiktet. Dette oppsto samtidig med oppussingsarbeid i hjemmet der flere rom ble malt. Det ble benyttet vannbasert maling. De siste fire årene hadde hun hatt flere episoder med eksem i ansiktet. Hun mistenkte reaksjon på solkremer i minst to av tilfellene.

Epikutantesting viste kraftig allergisk reaksjon for konserveringsmidlene metylkloroisothiazolinon og metylisothiazolinon. Hun hadde ingen reaksjoner ved epikutantesting med solkremallergener. Brukertest ble ikke utført. Utslettet forsvant gradvis etter at malingsarbeidet var fullført og med samtidig seponering av kosmetiske preparater.

De nevnte konserveringsmidlene brukes i hudprodukter, rengjøringsmidler, poleringsmidler og vannbaserte malinger. Klorforbindelsen, metylkloroisothiazolinon, er mest allergen $(1,2)$. Tidligere ble kombinasjonen metylkloroisothiazolinon/metylisothiazolinon benyttet som konserveringsmiddel i hudkremer, men etter år 2005 brukes metylisothiazolinon hyppigere $(1,2)$. Det er deretter påvist økende forekomst av allergi overfor metylisothiazolinon i flere europeiske land (2). Relativt høye konsentrasjoner av metylkloroisothiazolinon/metylisothiazolinon kan fortsatt finnes, blant annet i sjampoer og rengjøringsmidler (3). Vannbasert maling konserveres ofte med disse produktene, men i lavere konsentrasjoner (1).

Vår pasient var sannsynligvis blitt sensibilisert ved bruk av hudpleieprodukter som inneholder metylkloroisothiazolinon/metylisothiazolinon. Kontaktallergisk eksem har senere oppstått ved direkte hudkontakt (hudkremer, sjampoer) og nå ved luftbåren kontakt (avdunsting fra maling). Sistnevnte reaksjonsmåte er beskrevet ved flere allergener, inkludert metylkloroisothiazolinon/ metylisothiazolinon, og må vurderes når pasienter har denne typen ansiktsdermatitt. Konsentrasjonen av metylkloroisothiazolinon/metylisothiazolinon i luften i nymalte rom er imidlertid så lav at det trolig bare er tidligere sensibiliserte personer som vil utvikle eksem.

\section{Pasienten har gitt samtykke til at artikkelen og bil-} det blir publisert.
Engelsk oversettelse på www.tidsskriftet.no

Bjarte Steinkjer (f.1954) er seksjonsoverlege. Forfatter har fylt ut ICMJE-skjemaet og oppgir ingen interessekonflikter.

\section{Litteratur}

1. Schwensen JF, Lundov MD, Bossi R et al. Methylisothiazolinone and benzisothiazolinone are widely used in paint: a multicentre study of paints from five European countries. Contact Dermat 2015; 72 $127-38$.

2. Gonçalo M, Goossens A. Whilst Rome burns: the epidemic of contact allergy to methylisothiazolinone. Contact Dermat 2013; 68: 257-8.

3. Aerts $\mathrm{O}$, Meert H, Goossens A et al. Methylisothiazolinone in selected consumer products in Belgium: Adding fuel to the fire? Contact Dermat 2015; 73: 142-9.

Mottatt 2.6. 2015, første revisjon innsendt 25.8. 2015, godkjent 27.8. 2015. Redaktør: Inge Rasmus Groote.

\section{Bjarte Steinkjer}

stbj@sus.no

Hudavdelingen

Stavanger universitetssjukehus 